\title{
MODEL TO ESTIMATE NUTRITIONAL AND NON-NUTRITIONAL LIMITATIONS OF 'PRATA-AN A' BANANA CROPS GROWN IN DIFFERENT ENVIRONMENTS ${ }^{1}$
}

\author{
VAGNER ALVES RODRIGUES FILHO ${ }^{2}$, JÚLIO CÉSAR LIMA NEVES ${ }^{3}$, SÉRGIO LUIZ RODRIGUES DONATO ${ }^{4}$
}

\begin{abstract}
The obtaining of a high banana yield requires that nutrients are in adequate quantities and proportions in the plant. Therefore, the use of methods that encompass nutritional balance and equilibrium is required for a good nutritional evaluation. The objective of this work was to model and determine nutritional and non-nutritional limitations of 'Prata-Anã' banana grown in the states of Ceará (CE) and Bahia (BA), Brazil, based on nutritional balance and equilibrium. The study was developed using the databank of leaf nutrient contents and banana yields of two farms of the Sítio Barreiras company, in Missão Velha (CE) and Ponto Novo (BA), Brazil. The parcels with banana yield above the average plus 0.5 standard deviation; and parcels with banana yield below of that limit were defined as low-yield areas and were used for nutritional diagnosis. The databank was divided into four: the first with 253 samples and a reference population with banana yield above $39.81 \mathrm{Mg} \mathrm{ha}^{-1}$ year $^{-1}$; the second with 553 samples and a low-yield population (Ceará); the third with 147 samples and a reference population with banana yield above $41.69 \mathrm{Mg} \mathrm{ha}^{-1}$ year $^{-1}$; and the fourth with 334 samples and a low-yield population (Bahia). Yield limitations in the 'Prata-Anã' banana crops due to nutritional causes reached $13.37 \%$ in Ceará, and $12.17 \%$ in Bahia. Non-nutritional factors, such as climate and biotic factors, limited the banana crop yields by up to $28.23 \%$ in Ceará, and $50.49 \%$ in Bahia.
\end{abstract}

Keywords: Musa spp. AAB. Diagnosis methods. Balance level. Equilibrium level.

\section{MODELO PARA ESTIMAR LIMITAÇÕES NUTRICIONAIS E NÃO NUTRICIONAIS EM BANANEIRAS 'PRATA-ANÃ' CULTIVADAS EM DIFERENTES AMBIENTES}

\begin{abstract}
RESUMO - A obtenção de um alto rendimento de banana requer que os nutrientes estejam em quantidades e proporções adequadas na planta. Portanto, a utilização de métodos que englobem o balanço e equilíbrio nutricional é necessária para uma boa avaliação nutricional. O objetivo deste trabalho foi modelar e determinar as limitações nutricionais e não nutricionais de bananeiras 'Prata-Anã' cultivadas nos estados do Ceará (CE) e Bahia (BA), Brasil, com base no balanço e equilíbrio nutricional. O estudo foi desenvolvido utilizando o banco de dados de teores de nutrientes nas folhas e produção de banana de duas fazendas da empresa Sítio Barreiras, em Missão Velha (CE) e Ponto Novo (BA), Brasil. As parcelas com produtividade de banana acima da média mais 0,5 desvio padrão foram definidas como população de referência; e parcelas com produtividade de banana abaixo desse limite foram definidas como áreas de baixa produtividade e utilizadas para diagnóstico nutricional. O banco de dados foi dividido em quatro: o primeiro com 253 amostras da população com produtividade de banana acima de $39,81 \mathrm{Mg} \mathrm{ha}^{-1} \mathrm{ano}^{-1}$; a segunda com 553 amostras e população de baixo rendimento (Ceará); a terceira com 147 amostras da população com produtividade de banana acima de $41,69 \mathrm{Mg} \mathrm{ha}^{-1}$ ano $^{-1}$; e a quarta com 334 amostras e população de baixo rendimento (Bahia). A limitação de produtividade da banana 'Prata-Anã' por causas nutricionais atingiu 13,37\% no Ceará, e 12,17\% na Bahia. Fatores não nutricionais, como clima e fatores bióticos, limitaram a produtividade da banana em até $28,23 \%$ no Ceará, e 50,49\% na Bahia.
\end{abstract}

Palavras-chave: Musa spp. AAB. Métodos de diagnóstico. Grau de balanço. Grau de equilíbrio.

\footnotetext{
${ }^{*}$ Corresponding author

${ }^{1}$ Received for publication in 10/17/2020; accepted in 10/27/2020

Paper extracted from the Masters dissertation of the first author.

${ }^{2}$ Technical Sector, Sítio Barreiras Fruticultura Ltda., Missão Velha, CE, Brazil; vagner@sitiobarreiras.com.br - ORCID: 0000-0001-77027445.

${ }^{3}$ Departament of Soils, Universidade Federal de Viçosa, Viçosa, MG, Brazil; julio_n2003@yahoo.com.br - ORCID: 0000-0001-83565100 .

${ }^{4}$ Agriculture Sector, Instituto Federal de Educação, Ciência e Tecnologia Baiano, Guanambi, BA, Brasil; sergio.donato@ifbaiano.edu.br ORCID: 0000-0002-7719-4662.
} 


\section{INTRODUCTION}

Brazil is the fourth largest banana producing country, after India, China, and Indonesia, with 6.67 million $\mathrm{Mg}$ over an area of 465,400 ha, and a mean yield of $14.34 \mathrm{Mg} \mathrm{ha}^{-1}$ (FAO, 2019). Despite this high production and large producing area, banana yield in Brazil is well below those of other countries, such as Costa Rica, Indonesia, Guatemala, Ecuador, India, and China.

Understanding processes related to nutrition of fruit and identifying limiting factors for banana yield require diagnosis methods and ability to isolate nutritional and non-nutritional factors. Environmental and biological factors may affect banana yield even when there are no nutritional factors involved.

The obtaining of a high banana yield requires that the nutrients in plants are in adequate amounts and proportions. Therefore, the use of methods that encompass nutritional balance and equilibrium is required for a good nutritional evaluation. The use of two or more methods of nutritional diagnosis enables a better diagnosis by complementarity (BLANCOMACÍAS et al., 2010; ALMEIDA et al., 2016).

In this context, the Balance Index Method of Kenworthy (1961) (BIMK) and the Diagnose and Recommendation Integrated System (DRIS) (BEAUFILS, 1973) are recommended for evaluations of nutritional balance and equilibrium, respectively.

The objective of this work was to model and determine nutritional and non-nutritional limitations of 'Prata-Anã' banana grown in the states of Ceará (CE) and Bahia (BA), Brazil, based on nutritional balance and equilibrium.

\section{MATERIAL AND METHODS}

The study was developed using the databank of leaf nutrient contents and banana yields of two farms of the Sítio Barreiras company, one in the municipality of Missão Velha, state of Ceará $\left(7.3590^{\circ} \mathrm{S}, 39.2117^{\circ} \mathrm{W}\right.$, and altitude of $\left.442 \mathrm{~m}\right)$ and other in the municipality of Ponto Novo, state of Bahia $\left(10.5146^{\circ} \mathrm{S}, 40.0801^{\circ} \mathrm{W}\right.$, and altitude of 362 m), Brazil.

The climate of the region of Missão Velha, $\mathrm{CE}$, is Aw, tropical, with a dry season in the winter and rainfall concentrated in the summer, according to the Köppen-Geiger classification, with a mean annual rainfall depth of $942 \mathrm{~mm}$ and a mean annual temperature of $25.8^{\circ} \mathrm{C}$. The soil of the area was classified as a Oxisol (Latossolo Vermelho-Amarelo distrófico) of weak A horizon and sandy texture. The area presented 57 parcels with fertigated 'Prata-Anã' banana (AAB), with a mean area of 3.26 ha.

The climate of the region of Ponto Novo, BA, is also Aw, according to the Köppen-Geiger classification, with a mean annual rainfall depth of $696 \mathrm{~mm}$ and a mean annual temperature of $24.1{ }^{\circ} \mathrm{C}$. The soil of the area was classified as a Oxisol (Latossolo Amarelo distrófico) of weak A horizon and sandy texture. The area presented 100 parcels with fertigated 'Prata-Anã' banana, with a mean area of 4.53 ha.

The chemical characteristics of the soils are shown in Table 1. The data were based on the databank of Soil Analyses of the evaluated farms in Missão Velha (CE) and in Ponto Novo (BA). The soil $\mathrm{pH}$ was evaluated in water at the ratio of $1: 2.5$; $\mathrm{P}, \mathrm{K}^{+}$were extracted by Mehlich-1; $\mathrm{Ca}^{2+}$ and $\mathrm{Mg}^{2+}$ were extracted by $\mathrm{KCl} 1 \mathrm{~mol} \mathrm{~L}^{-1}$; soil organic matter contents were evaluated by multiplying the organic carbon by 1.724 (Walkley-Black); and the soil cation exchange capacity was evaluated at $\mathrm{pH}$ 7.0. The meteorological data of the areas, according to the meteorological databanks of automatic weather stations installed in the farms are shown in Table 2.

Table 1. Chemical properties of the $0.00-0.20$ and $0.20-0.40 \mathrm{~m}$ layers of soils with 'Prata-Anã' banana, in Missão Velha, $\mathrm{CE}$, and Ponto Novo, BA, Brazil.

\begin{tabular}{|c|c|c|c|c|c|c|c|c|c|c|}
\hline \multirow{2}{*}{ Area } & Layer & $\overline{\mathrm{pH}}\left(\mathrm{H}_{2} \mathrm{O}\right)$ & $\mathrm{SOM}$ & $\bar{P}$ & $\mathrm{~K}^{+}$ & $\mathrm{Ca}^{2+}$ & $\mathrm{Mg}^{2+}$ & $\mathrm{CEC}$ & \multirow{2}{*}{$\begin{array}{l}\mathrm{V} \\
\%\end{array}$} & \multirow{2}{*}{$\begin{array}{l}\text { P-Rem } \\
\mathrm{mg} \mathrm{L}^{-1}\end{array}$} \\
\hline & $\mathrm{m}$ & & $\mathrm{g} \mathrm{dm}^{-3}$ & $\mathrm{mg} \mathrm{dm}{ }^{-3}$ & \multicolumn{4}{|c|}{$\mathrm{mmol}_{\mathrm{c}} \mathrm{dm}^{-3}$} & & \\
\hline \multirow{2}{*}{ Missão Velha } & $0.00-0.20$ & 7.1 & 21.3 & 121.9 & 4.7 & 61.1 & 16.0 & 93.6 & 83.4 & 53.4 \\
\hline & $0.20-0.40$ & 8.0 & 29.0 & 140.0 & 9.0 & 132.0 & 25.0 & 175.1 & 94.8 & 49.8 \\
\hline \multirow{2}{*}{ Ponto Novo } & $0.00-0.20$ & 6.4 & 15.0 & 66.2 & 2.7 & 20.0 & 7.0 & 52.0 & 46.1 & 64.0 \\
\hline & $0.20-0.40$ & 6.4 & 12.0 & 21.0 & 2.1 & 11.0 & 5.0 & 38.0 & 58.0 & 44.6 \\
\hline
\end{tabular}

$\mathrm{pH}$ in water in a 1:2.5 ratio; $\mathrm{SOM}: \mathrm{SOM}=$ soil organic matter contents; $\mathrm{CEC}=$ cation exchange capacity at $\mathrm{pH} 7 ; \mathrm{V}=$ base saturation; P-rem: P-remaining.

Source: Production of the author from the databank of Soil Analyses of the farms in Missão Velha (CE) and Ponto Novo (BA). 
V. A. RODRIGUES FILHO et al.

Table 2. Meteorological data recorded by automatic weather stations in the farms in Missão Velha (CE) and Ponto Novo (BA), in 2016.

\begin{tabular}{|c|c|c|c|c|c|c|c|}
\hline Month & $\begin{array}{c}\text { Mean } \\
\text { Temperature } \\
\left({ }^{\circ} \mathrm{C}\right)\end{array}$ & $\begin{array}{c}\text { Maximum } \\
\text { Temperature } \\
\left({ }^{\circ} \mathrm{C}\right)\end{array}$ & $\begin{array}{c}\text { Minimum } \\
\text { Temperature } \\
\left({ }^{\circ} \mathrm{C}\right)\end{array}$ & $\begin{array}{c}\text { Rainfall } \\
\text { depth } \\
(\mathrm{mm})\end{array}$ & $\begin{array}{l}\text { Relative air } \\
\text { humidity } \\
(\%)\end{array}$ & $\begin{array}{c}\text { Vapor } \\
\text { pressure } \\
\text { deficit }(\mathrm{kPa})\end{array}$ & $\begin{array}{c}\text { Maximum } \\
\text { wind speed } \\
\left(\mathrm{m} \mathrm{s}^{-1}\right)\end{array}$ \\
\hline \multicolumn{8}{|c|}{ Missão Velha - CE } \\
\hline January & 26.91 & 31.96 & 21.86 & 231.10 & 74.22 & 0.76 & 1.60 \\
\hline February & 26.95 & 33.17 & 20.73 & 60.90 & 77.61 & 0.67 & 1.60 \\
\hline March & 27.79 & 33.38 & 22.21 & 198.50 & 78.13 & 0.68 & 1.54 \\
\hline April & 27.05 & 32.84 & 21.26 & 33.50 & 74.05 & 0.78 & 3.09 \\
\hline May & 27.14 & 33.40 & 20.88 & 30.00 & 66.65 & 1.01 & 3.09 \\
\hline June & 26.23 & 32.64 & 19.82 & 17.60 & 64.00 & 1.05 & 7.72 \\
\hline July & 26.39 & 33.22 & 19.57 & 0.00 & 50.60 & 1.46 & 5.14 \\
\hline August & 27.00 & 34.68 & 19.32 & 0.00 & 45.92 & 1.67 & 5.14 \\
\hline September & 28.29 & 35.58 & 21.01 & 3.10 & 45.66 & 1.78 & 4.63 \\
\hline October & 29.26 & 36.72 & 21.81 & 0.00 & 44.07 & 1.93 & 3.60 \\
\hline November & 29.67 & 36.32 & 23.03 & 0.00 & 43.41 & 1.97 & 3.09 \\
\hline December & 29.04 & 35.61 & 22.47 & 69.10 & 52.98 & 1.58 & 3.09 \\
\hline \multicolumn{8}{|c|}{ Ponto Novo - BA } \\
\hline January & 25.19 & 29.84 & 22.37 & 190.83 & 82.92 & 0.48 & 5.18 \\
\hline February & 25.83 & 31.86 & 21.08 & 20.80 & 74.06 & 0.75 & 5.98 \\
\hline March & 26.90 & 32.95 & 21.85 & 0.00 & 69.02 & 0.94 & 6.58 \\
\hline April & 26.51 & 32.63 & 21.37 & 14.45 & 64.73 & 1.05 & 5.58 \\
\hline May & 24.48 & 29.58 & 20.45 & 49.25 & 76.05 & 0.64 & 6.21 \\
\hline June & 23.12 & 27.93 & 19.47 & 31.55 & 78.08 & 0.54 & 5.68 \\
\hline July & 22.60 & 28.29 & 18.16 & 8.85 & 75.48 & 0.60 & 6.11 \\
\hline August & 23.33 & 29.25 & 18.57 & 11.75 & 71.71 & 0.72 & 6.50 \\
\hline September & 24.48 & 30.63 & 19.66 & 1.80 & 69.65 & 0.82 & 6.75 \\
\hline October & 25.99 & 32.57 & 20.86 & 5.95 & 66.99 & 0.98 & 7.10 \\
\hline November & 24.53 & 25.23 & 23.82 & 184.00 & 70.79 & 0.74 & 1.34 \\
\hline December & 25.2 & 25.98 & 24.42 & 44.20 & 69.49 & 0.80 & 1.32 \\
\hline
\end{tabular}

Results of leaf tissue analyses from the databank of the Sítio Barreiras company were used. These data were from analyses done over several years, and included the banana yield of each parcel.

The leaf tissues were sampled according to recommendations of Rodrigues et al. (2010) and Costa et al. (2019). The sampling consisted of collecting the central part of the blade of the third leaf from the apex of plants at inflorescence stage, presenting two to three opened male bunches. The samples were processed and analyzed for macronutrients $(\mathrm{N}, \mathrm{P}, \mathrm{K}, \mathrm{Ca}, \mathrm{Mg}$, and $\mathrm{S})$ and micronutrients ( $\mathrm{B}, \mathrm{Cu}, \mathrm{Fe}, \mathrm{Mn}$, and $\mathrm{Zn}$ ), according to Sofi et al. (2017).

The banana yields were estimated in $\mathrm{Mg} \mathrm{ha}{ }^{-1}$ year $^{-1}$ by weighing the bunches at the harvest. The leaf analyses were done twice a year. The parcels with banana yield above the average (mean plus 0.5 standard deviation) were defined as high-yield areas and their plants were used as a reference population to develop standards for the Balance Index Method of Kenworthy (1961) (BIMK) and the Diagnose and Recommendation Integrated System (DRIS) (BEAUFILS, 1973); and parcels with banana yield below of this limit were defined as low-yield areas and used for nutritional diagnosis.

The databank was divided into four databank groups, considering the environments and banana yields. The first and second databanks were from the
Missão Velha, CE, with results of leaf tissue analyses collected twice a year and annual banana yields from 2010 to 2017 . The yield databank had 806 yield records showing a mean \pm standard deviation of $35.91 \pm 7.8 \mathrm{Mg} \mathrm{ha}^{-1}$ year $^{-1}$ and was divided into low- and high-yield populations; the high-yield population, with banana yield of 39.81 $\mathrm{Mg} \mathrm{ha} \mathrm{year}^{-1}$ (72.72\% of the maximum yield) and 253 samples, and the low-yield population with 553 samples. The third and fourth databank were from the Ponto Novo, BA, with results of leaf tissue analyses collected twice a year and annual banana yields from 2014 to 2016 . The databank yield had 481 records showing a mean \pm standard deviation of $34.89 \pm 13.59 \mathrm{Mg} \mathrm{ha}^{-1}$ year $^{-1}$ and was divided into low- and high-yield populations: the high-yield population with $41.69 \mathrm{Mg} \mathrm{ha}^{-1}$ year $^{-1}(57.00 \%$ of the maximum yield) and 147 samples; and the low-yield population with 334 samples.

The mean and variability of leaf nutrient contents in the sampled population were evaluated, and the nutritional indexes were calculated by BIMK and DRIS, according to Rodrigues Filho (2018), whose standards of the reference population established for the same place and banana variety were used as parameters for nutritional diagnosis.

The indexes found by BIMK and DRIS for each nutrient in the nutritional diagnosis were substituted in the potential response curves obtained 
by the boundary line method. Thus, the estimated relative yield of the banana plants was obtained according to the limitation caused by the balance or imbalance level of each nutrient.

The lowest estimated relative yield was selected among the nutrients based on the Liebig's Law of the Minimum, considering the nutritional balance or equilibrium to identify the most limiting nutrient for banana yield. The nutritional limitation was then evaluated using Equation 1:

$$
N L=100 \%-E R Y
$$

where $N L$ is the nutritional limitation (\%); Estimated Relative Yield obtained using the potential nutrient-response curve (\%); and $100 \%$ is the ideal value of each nutrient for the plants to be under nutritional balance and equilibrium. Thus, the banana yield losses associated with nutritional factors were obtained.

The banana yield losses associated with nonnutritional factors were obtained using Equation 2:

$$
N N L=E R Y-A R Y
$$

where $N N L$ is the non-nutritional limitation (\%); $A R Y$ is the Actual Relative Yield, calculated based on the highest yield (\%).

\section{RESULTS AND DISCUSSION}

The potential response curves for levels of nutritional balance and nutritional equilibrium used to determine the limitation of banana yields caused by each nutrient developed by Rodrigues Filho (2018) are shown in Figures 1, 2, 3 and 4.

The quantitative participation of nonnutritional factors for the limitation of banana yields is shown in Table 3. Mn was the most limiting nutrient for banana yield of the farm in Missão Velha, CE, considering the nutritional balance level, presenting an estimated relative yield of $86.63 \%$ (Table 3); and $\mathrm{S}$ was the most limiting nutrient, considering the nutritional equilibrium level, with an estimated relative yield of $87.92 \%$. Thus, the maximum banana yield that could be reached would be $86.63 \%$ for conditions of $100 \%$ nutritional balance and equilibrium. Therefore, the farm in Missão Velha, CE, supposedly had a banana yield loss of $13.37 \%$ caused by an inappropriate nutrition.

$\mathrm{S}$ was the most limiting nutrient for banana yield of the farm in Ponto Novo, BA, considering the nutritional balance level, which presented an estimated relative yield of $88.04 \%$; and $\mathrm{P}$ was the most limiting nutrient, considering the equilibrium level, with an estimated relative yield of $87.83 \%$. Thus, the maximum banana yield that could be reached would be $87.83 \%$, for $100 \%$ nutritional balance and equilibrium. Therefore, the farm in Ponto Novo, BA, supposedly had a banana yield loss of $12.17 \%$ due to an inappropriate nutrition.

The farm in Missão Velha, CE, presented an actual relative yield of $58.40 \%$, which would be higher, approximately $86.63 \%$, when considering only the limitations caused by the plant nutritional status. The actual relative yield was lower than the estimated banana yield, indicating that $28.23 \%$ of the banana yield was limited by other factors (nonnutritional), such as the local climate. The high temperatures from August to December (above $34^{\circ}$ C), low relative air humidity (lower than $50 \%$ ), and high vapor pressure deficit (Table 2) in the region can cause thermal stress to banana, with decreases in photosynthesis rates and, consequently, banana yields (ARANTES et al., 2016; 2018; RAMOS et al., 2018).

The farm in Ponto Novo, BA, presented an actual relative yield of $37.34 \%$, which would be higher, approximately $87.83 \%$, when considering only the limitations caused by the plant nutritional status. The actual relative yield was lower than the estimated banana yield, indicating that $50.49 \%$ of the banana yield was limited by other factors (nonnutritional), such as the climate. Despite the region of the farm in Ponto Novo, BA (Table 2) presents mild maximum temperatures, except from February to April, and relative air humidity above $60 \%$ throughout the year, the maximum wind speed is above $5 \mathrm{~m} \mathrm{~s}^{-1}$ (except from November to December), which can damage the leaf blade, reducing the leaf area and, consequently, photosynthetic rates and banana yields (DONATO et al., 2016).

In addition, biotic factors, including incidence of pests and diseases, such as the wither caused by the fungus Fusarium oxysporum f. sp. cubense, may have limited the banana yield in both farms, considering that this pathogen is well disseminated in these areas.

Therefore, a proposal for more accurate interpretive diagnostics and cultural managements in the context of this discussion (DONATO et al., 2017) requires to consider the interactions between different factors (nutrient contents, solar radiation, water availability, temperature, and soil aeration) that affect the nutrient flow in the soil-plant system. This is required because the soil and its relation with plants and atmosphere is irreplaceable to predict nutrient availability to plants, which is not possible only by chemical analyses of soils and plant tissues (RESENDE; CURI; LANI, 2002). 

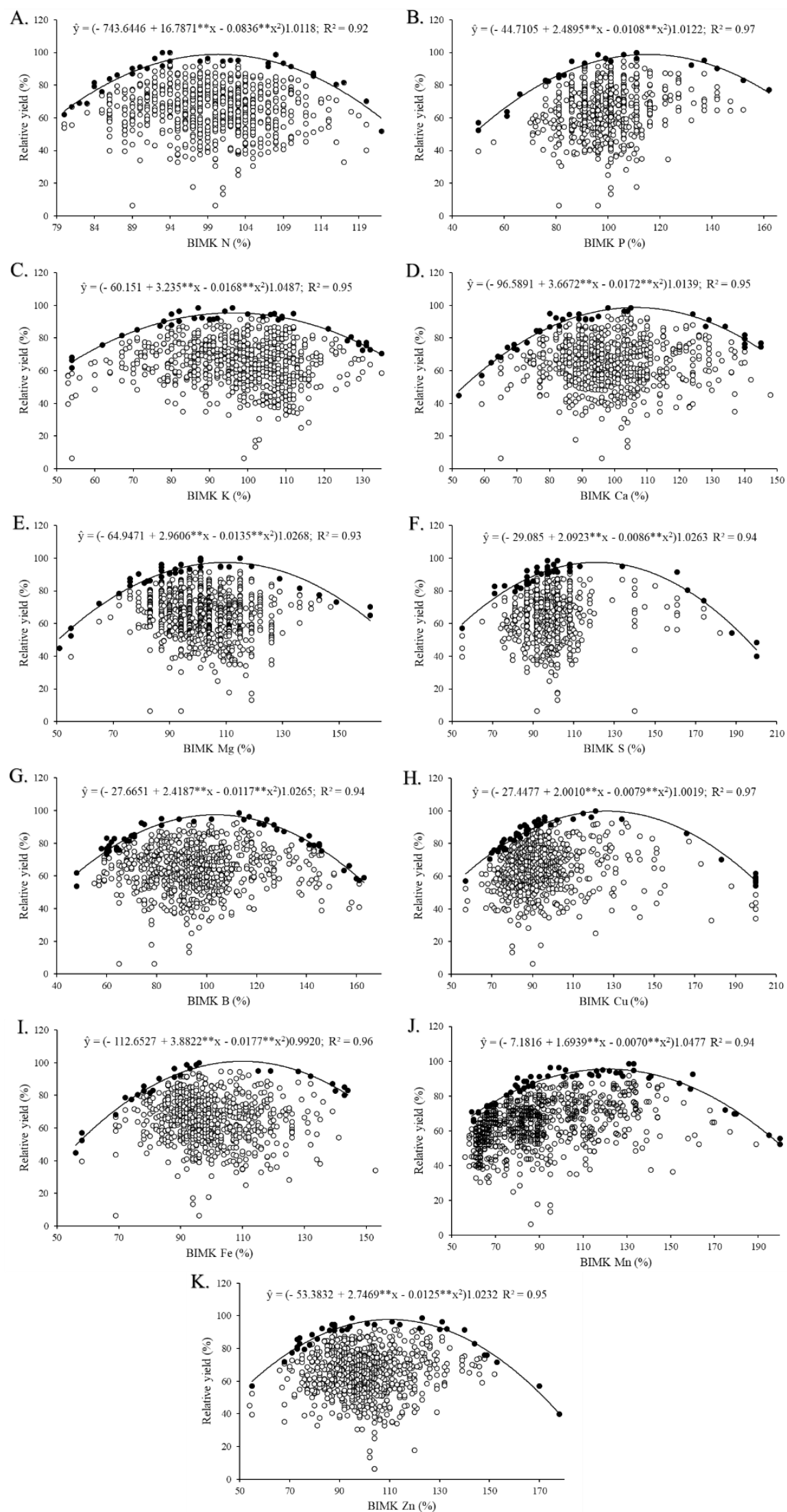

Figure 1. Boundary line estimated for relative yield (\%) as a function of Kenworthy indexes for N (A), P (B), K (C), Ca (D), $\mathrm{Mg}(\mathrm{E}), \mathrm{S}(\mathrm{F}), \mathrm{B}(\mathrm{G}), \mathrm{Cu}(\mathrm{H}), \mathrm{Fe}(\mathrm{I}), \mathrm{Mn}(\mathrm{J})$, and $\mathrm{Zn}(\mathrm{K})$ in leaves of 'Prata-Anã' banana grown in Missão Velha, CE, Brazil.

** - Significant at $\mathrm{p} \leq 0.01$ by the t-test; The multipliers $1.018 ; 1.0122$; etc. found in the equations correspond to an adjustment factor for the equation to assume the value of $100 \%$ Relative Yield. 

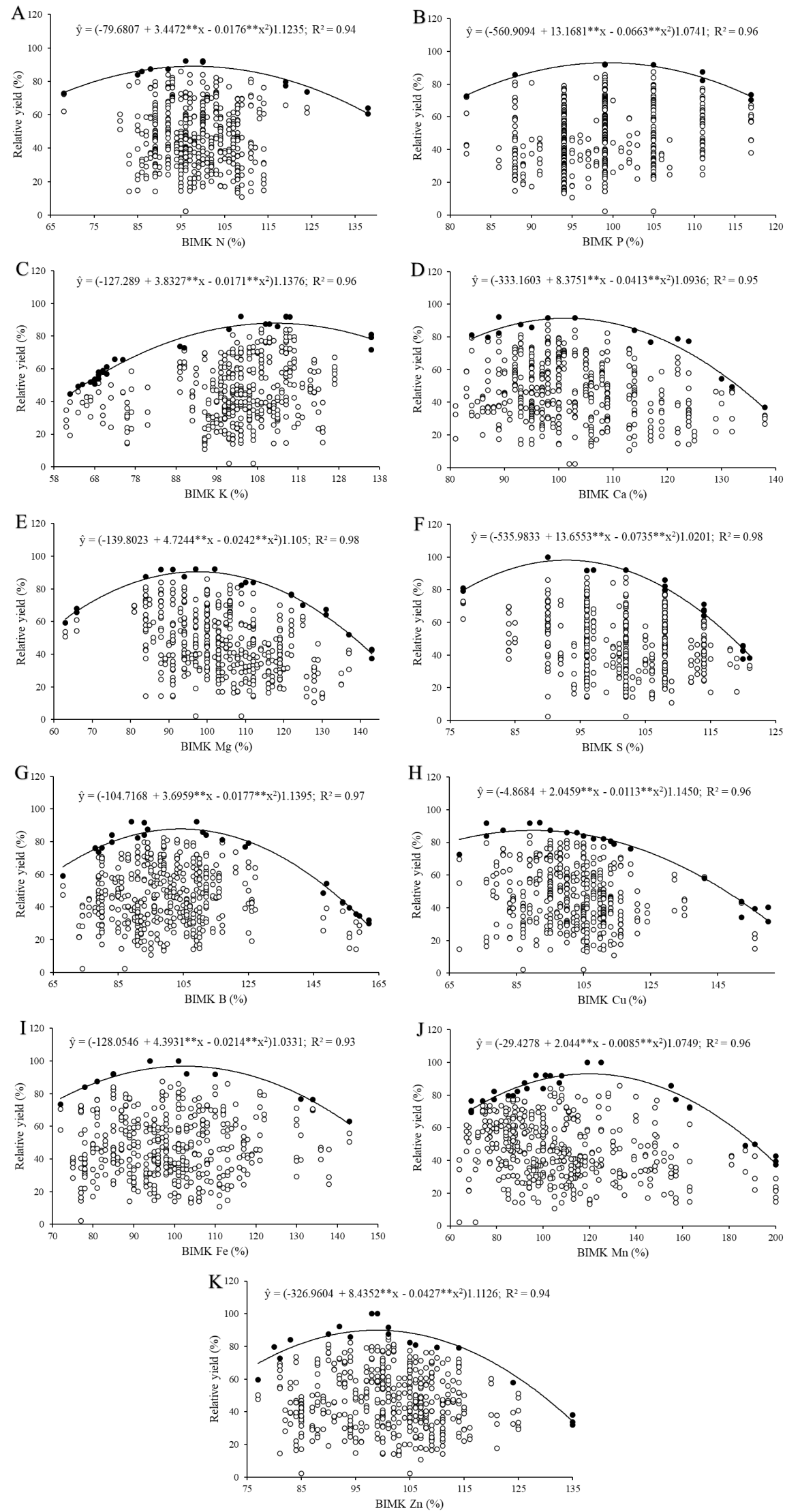

Figure 2. Boundary line estimated for relative yield (\%) as a function of Kenworthy indexes for N (A), P (B), K (C), Ca (D), Mg (E), S (F), B (G), Cu (H), Fe (I), Mn (J), and Zn (K) in leaves of 'Prata-Anã' banana grown in Ponto Novo, BA, Brazil.

** - Significant at $\mathrm{p} \leq 0.01$ by the t-test; The multipliers $1.1235 ; 1.0741$; etc. found in the equations correspond to an adjustment factor for the equation to assume the value of $100 \%$ Relative Yield. 

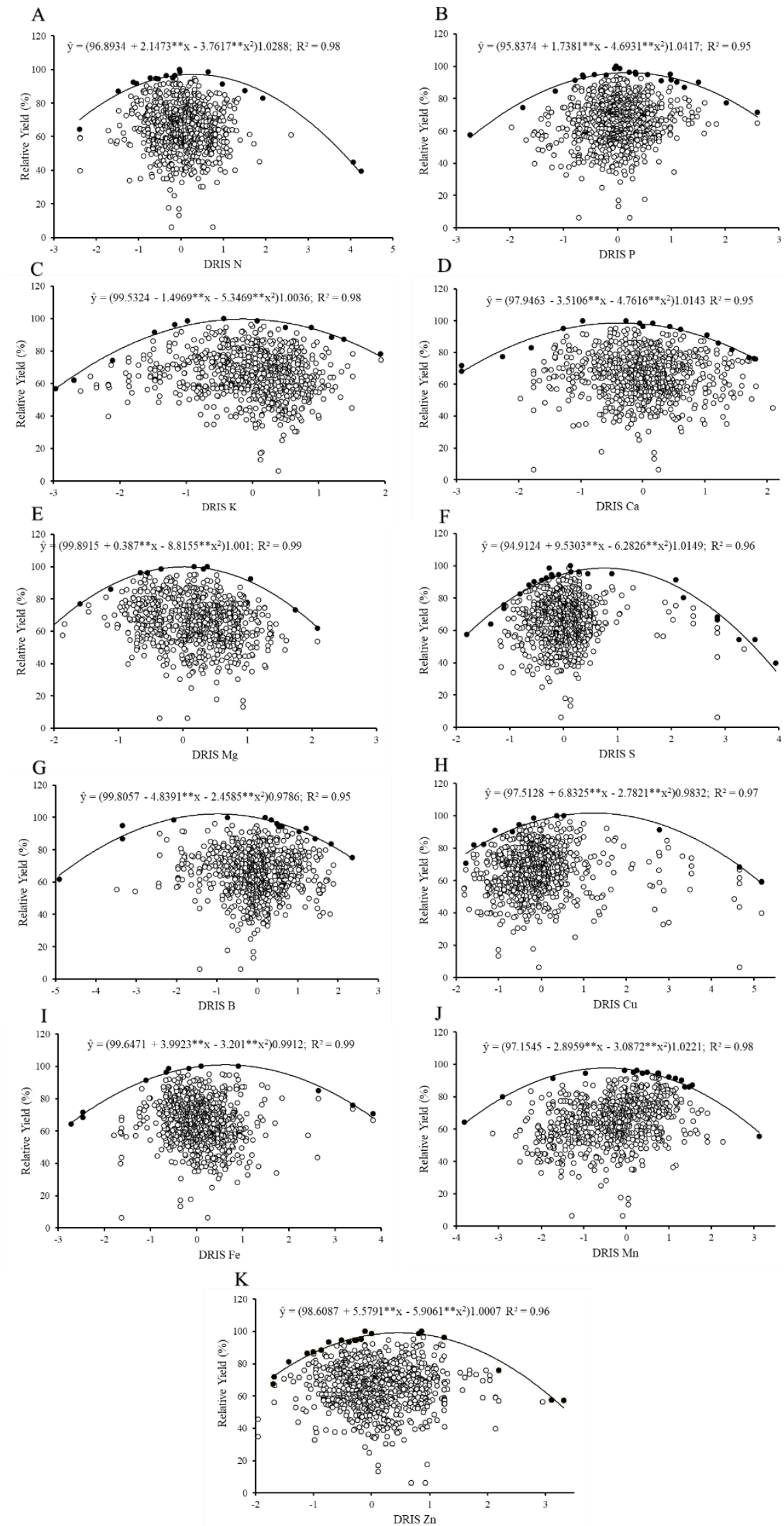

Figure 3. Boundary line estimated for relative yield (\%) as a function of DRIS indexes for N (A), P (B), K (C), Ca (D), Mg (E), S (F), B (G), Cu (H), Fe (I), Mn (J), and Zn (K) in leaves of 'Prata-Anã' banana grown in Missão Velha, CE, Brazil. ** - Significant at $\mathrm{p} \leq 0.01$ by the t-test; The multipliers $1.0288 ; 1.0417$; etc. found in the equations correspond to an adjustment factor for the equation to assume the value of $100 \%$ Relative Yield. 

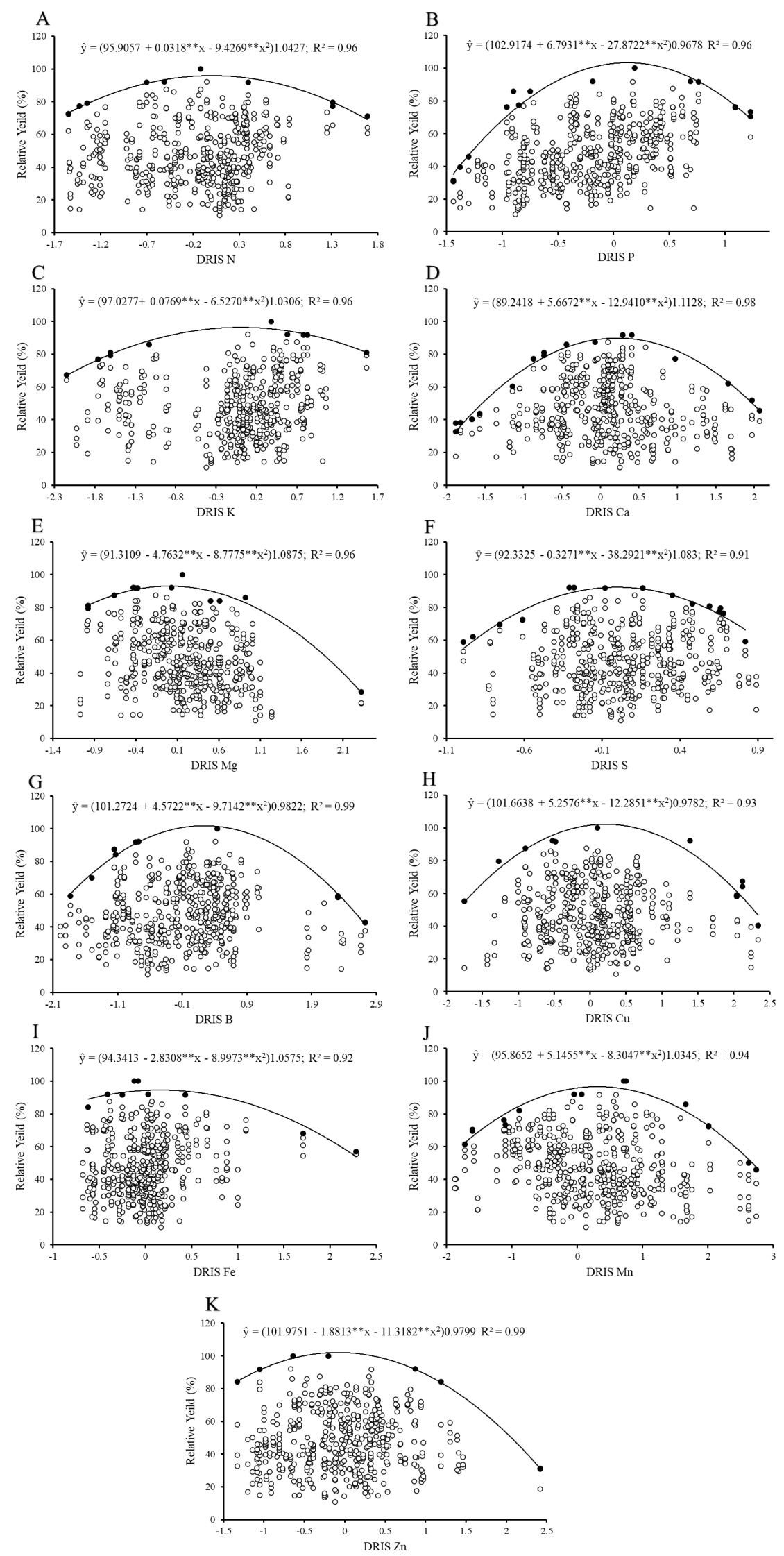

Figure 4. Boundary line estimated for relative yield (\%) as a function of DRIS indexes for N (A), P (B), K (C), Ca (D), Mg (E), S (F), B (G), Cu (H), Fe (I), Mn (J), and Zn (K) in leaves of 'Prata-Anã' banana grown in Ponto Novo, BA, Brazil. ** - Significant at $\mathrm{p} \leq 0.01$ by the t-test; The multipliers $1.0427 ; 0.9678$; etc. found in the equations correspond to an adjustment factor for the equation to assume the value of $100 \%$ Relative Yield. 
Table 3. Actual Relative Yield (ARY) and Estimated Relative Yield (ERY) of low-yield banana populations evaluated by the Balance Index Method of Kenworthy (BIMK) and the Diagnose and Recommendation Integrated System (DRIS) for 'Prata-Anã' banana grown in Missão Velha (CE) and Ponto Novo (BA), Brazil.

\begin{tabular}{|c|c|c|c|c|c|c|c|c|c|c|c|}
\hline \multicolumn{12}{|c|}{ BIMK - Missão Velha, CE } \\
\hline \multirow{2}{*}{ ARY (\%) } & \multicolumn{11}{|c|}{ Estimated Relative Yield - ERY (\%) } \\
\hline & $\mathrm{N}$ & $P$ & $\mathrm{~K}$ & $\mathrm{Ca}$ & $\mathrm{Mg}$ & $\mathrm{S}$ & $\mathrm{B}$ & $\mathrm{Cu}$ & $\mathrm{Fe}$ & $\mathrm{Mn}$ & $\mathrm{Zn}$ \\
\hline 58.40 & 95.57 & 94.95 & 95.98 & 95.10 & 96.81 & 92.69 & 94.23 & 87.07 & 93.88 & 86.63 & 94.61 \\
\hline \multicolumn{12}{|c|}{ DRIS - Missão Velha, CE } \\
\hline \multirow{2}{*}{ ARY (\%) } & \multicolumn{11}{|c|}{ Estimated Relative Yield - ERY (\%) } \\
\hline & $\mathrm{N}$ & $\bar{P}$ & $\mathrm{~K}$ & $\mathrm{Ca}$ & $\mathrm{Mg}$ & $\mathrm{S}$ & $\mathrm{B}$ & $\mathrm{Cu}$ & $\mathrm{Fe}$ & $\mathrm{Mn}$ & $\mathrm{Zn}$ \\
\hline 58.40 & 97.68 & 97.36 & 96.17 & 97.18 & 95.87 & 87.92 & 96.46 & 89.72 & 97.65 & 97.27 & 94.68 \\
\hline \multicolumn{12}{|c|}{ BIMK - Ponto Novo, BA } \\
\hline \multirow{2}{*}{ ARY (\%) } & \multicolumn{11}{|c|}{ Estimated Relative Yield - ERY (\%) } \\
\hline & $\mathrm{N}$ & $\bar{P}$ & $\bar{K}$ & $\mathrm{Ca}$ & $\mathrm{Mg}$ & $\bar{S}$ & $\mathrm{~B}$ & $\mathrm{Cu}$ & $\mathrm{Fe}$ & $\mathrm{Mn}$ & $\mathrm{Zn}$ \\
\hline 37.34 & 98.84 & 96.68 & 92.51 & 89.85 & 93.18 & 88.04 & 92.65 & 94.67 & 92.20 & 90.70 & 92.74 \\
\hline \multicolumn{12}{|c|}{ DRIS Ponto Novo, BA } \\
\hline \multirow{3}{*}{$\begin{array}{c}\text { ARY (\%) } \\
37.34\end{array}$} & \multicolumn{11}{|c|}{ Estimated Relative Yield - ERY (\%) } \\
\hline & $\mathrm{N}$ & $\bar{P}$ & $\overline{\mathrm{K}}$ & $\mathrm{Ca}$ & $\mathrm{Mg}$ & $\overline{\mathrm{S}}$ & $\bar{B}$ & $\mathrm{Cu}$ & $\mathrm{Fe}$ & $\mathrm{Mn}$ & $\mathrm{Zn}$ \\
\hline & 96.13 & 87.83 & 97.01 & 90.56 & 94.13 & 94.50 & 90.72 & 93.58 & 96.67 & 92.59 & 94.85 \\
\hline
\end{tabular}

The overall loss of banana yield, which is the difference between the maximum achievable yield $(100 \%)$ and the actual relative yield and denotes the total loss of banana yield considering nutritional and non-nutritional factors, were $41.6 \%$ for the farm in Missão Velha, CE, and $62.66 \%$ for the farm in Ponto Novo, BA.

The information presented in the present study may contribute to minimize misleading extrapolations by considering specificities, including the different environments and managements, and not only overall standards for diagnosis, regardless of how accurate and refined the tools available for diagnoses.

\section{CONCLUSIONS}

Yield limitations in 'Prata-Anã' banana crops due to nutritional causes reached $13.37 \%$ in the farm in Missão Velha, CE, and $12.17 \%$ in the farm in Ponto Novo, BA, Brazil.

Non-nutritional factors, such as climate and biotic factors, limited the yield of banana crops by $28.23 \%$ in the farm in Missão Velha, CE, and $50.49 \%$ in the farm in Ponto Novo, BA.

\section{ACKNOWLEDGEMENTS}

The authors thank the Mr. Fábio Régis de Albuquerque (Sítio Barreiras company) for providing the data for this research and a master's scholarship to the first author.

\section{REFERENCES}

ALMEIDA, E. I. B. et al. Linha de fronteira e chance matemática na determinação do estado nutricional de pitaia. Revista Ciência Agronômica, 47: 744-754, 2016.

ARANTES, A. M. et al. Gas exchange in 'Pome' banana plants grown under different irrigation systems. Engenharia Agrícola, 38: 197-207, 2018.

ARANTES, A. M. et al. Gas exchange in different varieties of banana prata in semi-arid environment. Revista Brasileira de Fruticultura, 38: 1-12, 2016.

BEAUFILS, E. R. Diagnosis and recommendation integrated system (DRIS). Soil Science. Bulletin $n^{\circ}$ 1. Pietermaritizburg, South Africa: University of Natal, 1973. 11 p.

BLANCO-MACÍAS, F. et al. Murillo $\square$ Amador, B. Nutritional reference values for Opuntia ficus $\square$ indica determined by means of the boundary $\square$ line approach. Journal of Plant Nutrition and Soil Science, 173: p. 927-934, 2010.

COSTA, L. G. D. A. F. et al. Seasonality in nutrient content of banana diagnostic leaf. Revista Brasileira de Fruticultura, 41, p. 1-8, 2019.

DONATO, S. L. R. et al. Considerações ecológicas, fisiológicas e de manejo. In: FERREIRA, C. F. et al. (Eds.). O agronegócio da banana. Brasília, DF: EMBRAPA, 2016. v. 1, cap. 03, p. 45-110. 
DONATO, S. L. R. et al. Diagnóstico nutricional e recomendação de adubação para a palma forrageira 'Gigante'. Informe Agropecuário, 38: 46-58, 2017.

\section{FOOD AND AGRICULTURAL ORGANIZATION}

- FAO. Faostat. Disponível em: <http:// www.faostat.fao.org/site/567/default.aspx.>. Acesso em: 28 set. 2019.

KENWORTHY, A. L. Interpreting the balance of nutrient-elements in leaves of fruit trees. In: REUTHER, W. (Ed.), Plant analysis and fertilizers problems. Washington, DC: American Institute of Biological Science, 1961, v. 1, p. 28-43.

RAMOS, A. G. O. et al. Evaluation of gas exchanges and production of genotypes of maçã banana type cultivated in the semi-arid region of Bahia. Revista Brasileira de Fruticultura, 40: 1-11, 2018.

RESENDE, M.; CURI, N.; LANI, J. L. Reflexões sobre o uso dos solos brasileiros. In: ÁLVAREZ V., V. H. et al. (Eds.). Tópicos em ciência do solo. Viçosa, MG: Sociedade Brasileira de Ciência do Solo, 2002. v. 2, p. 593-643.

RODRIGUES, M. G. V. et al. Amostragem foliar da bananeira 'Prata-Anã'. Revista Brasileira de Fruticultura, 32: 321-325, 2010.

RODRIGUES FILHO, V. A. Curvas de resposta potencial e faixas de suficiência nutricional para plantios irrigados de bananeiras Prata e Cavendish. 2018. 164 f. Dissertação (Mestrado em Fitotecnia: Área de concentração em Nutrição Mineral, Adubação e Produção de culturas), Universidade Federal de Viçosa, Viçosa, 2018.

SOFI, J. A. et al. Diagnosis and recommendation integrated system approach for major and micronutrient diagnostic norms for apple (Malus Domestica Borkh) under varying ages and management practices of apple orchards. Journal of Plant Nutrition, 40: 1784-1796, 2017. 